\title{
Doxa a epistémé zážitkové pedagogiky
}

\author{
IVo JiRÁSEK
}

\begin{abstract}
Abstrakt: Príspèvek podává formou prèledové studie predstavu o vývoji oboru na pomezí pedagogiky, andragogiky a kinantropologie, totiž o výchově v prírodè a jeji proměně v moderni formy výchovy v prírodè - prázdninovou pedagogiku a zážitkovou pedagogiku. Př́spèvek nejprve rekapituluje určitá kliséé, minèni a hodnoceni, která se soborem provazuji dle autora neprávem (doxa), totiž neodlišováni záżitkové pedagogiky v teorii a oboru praktického puisobení; v jejím pronikáni do školniho prostréedi v neadekvátní podobě; v nedoceňováni využití zážitku v pedagogickém diskursu; ve vnimání reflexe jako nezbytné soućásti tohoto typu osobnostniho rozvoje; ve vazbè na literárni zdroje pouze z posledního ćtvrtstoletí. Následnè text nabizi ideje, které autor považuje za relevantni porozumèni (epistémé), totiž že se zkušenost jako existenciálni fakt může stát prostredkem osobnostniho rozvoje; ta se vyznačuje holistickým rozmèrem piosobeni; nabizi rekapitulaci predchozich terminů označujicich zkoumanou problematiku, na jejichž pozadí lze hloubèji porozumèt historii a terminologickému vývoji oboru; a na závèr konstatuje nemožnost zařazeni tohoto specifického pedagogického tématu (či dokonce oboru) do prèhledné klasifikace pedagogických véd.
\end{abstract}

Kličová slova: zkušenost, zážitek, pohybová rekreace, výchova v př́rodě, zážitková pedagogika, pravdivé poznání.

\section{ÚVODEM}

$\mathrm{V}$ českých pedagogických kruzích bývá zvykem opř́t se ve svých argumentech o nezpochybnitelné autory, pokud možno př́ímo o citáty J. A. Komenského. Ani fenomén, s nímž se v poslední době setkáváme $\mathrm{v}$ teoretických textech i v edukační realitě, nazývaný zážitková pedagogika, nemusí být výjimkou. Stačí poukaz na Komenského zásady názornosti či aktivnosti, abychom vyvozovali apel na prrímou žákovu zkušenost. Nehledě na pedagogický význam hry, který se bez patřičného kontextu dává do souvislosti se vzděláním a sousloví „škola hrou“ se jako klišé a prázdná fráze ozývá v hučení davu. A přesto je nutné se $\mathrm{v}$ úvodní poznámce opřít o jiný než pedagogický spis ikony oboru. Ve své knize Theatrum universitatis rerum (Divadlo světa) totiž Komenský (1914) využívá renesanční figury divadla a procesu vidění jako podstaty poznávání a moudrosti („osvícení lidské“, „světle moudrý“, „prohlédání věcí v světěc) při hledání pravdy (resp. Pravdy). Pokusme se proto osvětlit pole a upřít koncentrovaný pohled na ten výsek reality, který se pod 
názvem zážitková pedagogika rozprostírá na pomezí pedagogiky, andragogiky, a kinantropologie a odlišit pravdivé poznání od pouhého mínění, jež pravdu zastiňuje.

Předběžně a předchůdně vymezme ono sémantické pole pomocí těchto limitních bodů:

- vyvolání silného prožitku, jeho metodicky vedené zpracování a převedení ve zkušenost;

- různorodost používaných programových prostředků (pohybové, tvořivostní, herní, diskusní aj.);

- jejich kontextové uspořádání pomocí principů dramaturgie do všestranně působícího celku;

- rozmanitost a atraktivita prostředí (přírodní scenérie skal, vodních ploch, lesů, cest, ale také budov a programových místností);

- využívání zejména volného času, s možností přesahu do profesionální praxe;

- realizace týmem edukátorů (učitelů, vychovatelů, instruktorů, lektorů), proškolených ve specifických dovednostech nezbytných $\mathrm{k}$ realizaci projektu;

- variabilita edukativních cílů (v personálním i sociálním rozměru) od rozvoje tvořivosti, manažerských dovedností či komunikace, týmové spolupráce a vedení skupin až po relaxaci, zvědomování „cesty k sobě“ a akcentaci spirituálního modu života.

Tento komplex praktických činností a metodických postupů budeme nazývat „holistickou výchovou“, nebot je účinek výše zmíněných projektů patrný $\mathrm{v}$ holistické zkušenosti, $v$ působení na existenciální rozměr lidského způsobu bytí, nikoliv pouze na vybrané (např. kognitivní či kreativní) jeho dimenze.

Potenciální teoretický (či přímo vědecký) obor „zážitková pedagogika“, který by takový výsek edukativní reality zkoumal, by musel usilovat o uchopení této holistické zkušenosti prostřednictvím slova a racionálních postupů vykazatelnosti, tedy $\log u$. Pro takové ucelené uspořádání poznatků tohoto praxí stvrzovaného působení však dosud nedisponujeme filosofickým modelem, jak může krátkodobá zkušenost proměnit celek jedincova života. Nehledě na nemožnost plně převést zážitek a zkušenost $\mathrm{v}$ plnosti jejich bytí do slov (pojednání o chuti čokolády či polibku nemůže samozřejmě zcela přenést prožitkové zanícení). Fakt, že takový obor není dosud teoreticky zakotven, však není totéž co radikální nemožnost jeho ustavení. Jestliže se v zahraničí s pojmy Erlebnispädagogik i experiential education pojí jak praktické a metodické otázky, tak teoretické a vědecké reflexe, neznamená to, že bychom měli trvale rezignovat na odlišení dimenzí výchovného působení a pedagogické teorie popisovaného výseku skutečnosti. Zdá se však v tuto chvíli, že pro prrísné vymezení předmětu zkoumání takového oboru chybí dosud zřetelný kategoriální aparát, který by napomohl striktnějšímu rozeznání zkušenosti (existenciálního faktu) $\mathrm{v}$ roli pedagogického prostředku, nebot rozvojově využitá zkušenost je holistický fenomén. A protože zážitková pedagogika je pouze novější název pro specificky českou tradici výchovy $\mathrm{v}$ př́ŕrodě, nezapadá ani do systému pedagogických věd. Pokud se však odřízne od svých kořenů, dochází 
k žalostným neporozuměním, sémantickým posunům a dezinterpretacím.

\section{Pravda a PRaVdivost: Problém FILOSOFIE A PEDAGOGIKY}

Starořecké pojetí pravdy jako alétheia, jako neskrytosti, resp. procesu umožňujícího přechod ze skrytu do světliny, možnost vyjít na světlo, nás nutí preferovat sokratovský dialog jako cestu pravého poznání $\mathrm{i}$ ve vědách o výchově. Chceme-li dosáhnout pravdivého poznání, musíme podstoupit cestu za to, co se pouze jeví $-\mathrm{v}$ našem př́padě se musíme odhodlat opustit pevně vykazatelné prostory didaktických metod a sestoupit do filosofického hájemství epistemologie (noetiky, gnozeologie), filosofické nauky zabývající se poznáním. Na rozdíl od adekvační (korespondenční) teorie pravdy Tomáše Akvinského, tedy tradičního pojetí bytnosti pravdy jako shody rozumu $s$ věcí (adequatio rei ad intellectum), se nemůžeme přidržet pouze roviny jazyka, tedy chápání soudu jako místa, $v$ němž se pravda nachází. Proto ani sémantická teorie pravdy, přecházející od definice pravdy ke kritériu pravdivosti (a požadující tak vedle materiální adekvace i formální korektnost), nemůže být hlavním metodickým postupem. Přednost musíme dát náhledu fundamentální ontologie, vnímající pravdu či smysluplnost jsoucna $\mathrm{v}$ jeho bytí, $\mathrm{v}$ postupném odhalování, a tudíž ve výše zmíněném procesu přechodu ze skrytosti do neskrytosti. Pravda není jazykovou výpovědí, pravda je existenciál, rys lidského způsobu bytí. Jeden z nejvý- znamnějších filosofů 20. století, Martin Heidegger, poukazuje velmi přesvědčivě, že vyjevování pravdy není čímsi automatickým: naopak, to, co již bylo odkryto, se musí znovu zajištovat proti zdání, nebot' i zdání je jakýmsi modem odkrytosti, kdy jsoucno „vypadá jako..., tzn. je již jistým způsobem odkryté, a přece ještě zastřené. Pravda (odkrytost) musí být na jsoucnu vždy znovu vydobyta“" (Heidegger, 1996, s. 252).

Existenciálně-ontologické souvislosti lidského způsobu bytí se pochopitelně projevují i v těch výsecích světa, jež lze uchopovat prostřednictvím pedagogických teorií. $\mathrm{K}$ možnosti bytí pravdy jako neskrytosti však bytostně patř́í rovněž řeč, nositelem oné odkrývající funkce je nutně logos. Ovšem výpověd' v diskursu pedagogiky disponuje obojí možností: jak odkrývající, tak zakrývající. A tak se znovu musíme potýkat $s$ problémem starořeckého myšlení platným již od Parmenida (Patočka, 1996; Svoboda, 1962), totiž odlišností doxa, zdání, mínění vyplývajícího zejména ze smyslových počitků, a epistémé, poznání racionálního a teoretického typu (př́padně, v Platonově pojetí, přímého nazírání reálného světa idejí). Tématem tohoto př́spěvku je otázka: jak je tomu s doxa a epistémé u fenoménu nazývaného „zážitková pedagogika“?

\section{ObTížE dialogu:}

\section{KOMPLEXNOST TÉMATU}

Zážitek jako centrální termín potenciálně konstituující specifičnost oboru zážitková pedagogika je sám o sobě nejenom 
odhalující (osobnostní rozvoj je často založen na personální, př́ímo prožité zkušenosti), ale současně zakrývající pravdivost reality i výpovědi o ní (rozhodně nestačí „jen zážitek“ či dokonce zábava, abychom získali oprávnění zařadit takové aktivity do pedagogického diskursu). Na počátku nového milénia jsme mohli být svědky vzedmuté vlny zájmu o toto téma, at už prezentované formou knižních publikací (Hájek, 2002; Hudlička, 2003; Jirásek, 2001), nebo sborníků ze série konferencí na téma prožitek (Kirchner, 2005; Kirchner \& Hogenová, 2001; Kirchner \& Kavalír, 2003; Kirchner \& Louka, 2007). Palčivost tehdejších diskusí již poněkud vyčpěla, urputná terminologická ohledávání blízkostí a odlišností trojice výrazů "prožitek - zážitek - zkušenost" se ustálila zejména na vnímání časového charakteru přítomnosti aktivního prožívání, minulostní dimenze uplynulého prožitku v modu vzpomínky či racionální analýzy, využívající termín zážitek, a zkušenosti coby potenciálního využití jádra prožité aktivity v odlišných situacích v budoucnosti. Jestliže je tedy zážitek zejména metodickou charakteristikou oboru (proces prožitých aktivit je často - nikoli však vždy - vědomě reflektován), zkušenost je jeho cílem. Můžeme se však setkat i s odlišným pojetím, vyhrazujícím pro slovo zážitek spíše modus každodennosti a pro pojem prožitek událost vymaňující se z řady ploché nerozlišitelnosti hlubokým zásahem do osobnostní struktury (Bednář, 2009).

Problém s navozováním prožitkových situací a jejich zážitkových reflexí v pe- dagogickém diskursu je spojen zejména se soudobým společenským vnímáním zážitku v rovině úniku a odreagování od pracovních povinností. Jako zjinačení každodennosti, adrenalinové extáze a labužnické sběratelství požitků je pojem zážitek zneužíván zejména $\mathrm{v}$ marketingových a reklamních sděleních - zážitkovou se nazývá nejenom pedagogika, ale také gastronomie, expozice, dárky i celé agentury prodávající iluze o možnostech zakusit něco mimořádného a originálního. Takto odlišné vnímání zážitku (jako hlubokého momentu formujícím osobnost verzus dimenze pomyslné atraktivity) vede $\mathrm{k}$ nemožnosti komunikačního porozumění při užívání tohoto termínu. Stírání sémantických hranic a rozostřování významů (resp. jejich rozšiřování) nutně vede $\mathrm{k}$ rozdílným pojetím nejenom role prožitku/zážitku, ale zejména jejich významu a smyslu, a to včetně jeho pedagogického využití. Ačkoliv souslovím „silný zážitek“ můžeme označit láskyplný vztah, kontakt se smrtí či náboženskou konverzi, snadno se (povýtce neadekvátně a nesprávně) připíná rovněž $\mathrm{k}$ večeři $s$ modelkou, $\mathrm{k}$ řízení auta nebo ke stř́lení z paintballové pistole. Hodnotová odlišnost zakotvení takových prožitků, a zejména pak různost jejich formativního působení na kvalitu života, je jistě intuitivně zřejmá.

A ještě jednou se dostáváme do potíží při snaze o adekvátní racionální vykázání a argumentační podloží toho, co se nazývá zážitkovou pedagogikou, odhlédneme-li od odlišností možných významů a variantních porozumění centrálnímu 
pojmu. Termín samotný nás totiž vede $\mathrm{k}$ problému nepřesnosti, nevymezenosti a neohraničenosti lidských prožitků (a tím patrně i oboru, který si zvolil daný pojem jako svoji specifikaci); nutně tak naráží na epistemologické odlišnosti vysvětlení a porozumění, jež se $\mathrm{k}$ prožitkům a jejich teoretické reflexi připínají z odlišných směrů jako adekvátní způsob jejich racionalizace. Je-li lidský způsob bytí, lidský život $\mathrm{v}$ jeho celkovosti výlučným tématem filosofické antropologie, jen obtížně můžeme chápat jeho jednotlivé části, momenty či okamžiky jinak než za pomoci dialektických vazeb celku a částí, holistických propojení a strukturálních vazeb - s ohledem na kategorii smyslu. Prožitek nestojí a nemůže stát netečně jako pevný objekt výzkumné či pedagogické utilizace, ale musí být respektována jeho vsazenost do kontextu života svého nositele, může být zvýznamňován pouze v kontextu individualizované osobnostní struktury. To znamená, že je lépe prístupen filosofickému tázání či vědeckému ohledávání stojícímu na kvalitativních prrístupech, se zázemím těch filosofických směrů, jež počítají s bytostnou nepřevoditelností kvality na její číselné vyjádření, tj. s fenomenologickými a hermeneutickými proudy myšlení, jež se cílevědomě definovaly již před stoletím jako opak pozitivismu. Epistemologické podloží úvah o zážitkové pedagogice tak nemůže být snadno akceptováno zastánci objektivistických názorů, kvantifikace idejí a chápání pravdy v jejím dvoupólovém uchopení výlučně nástroji výrokové logiky.

\section{Doxa VZTahující SE}

\section{K ZÁŽITKOVÉ PEDAGOGICE}

Výše připomenuté Heideggerovo (1996) upozornění, že poznávané jsoucno je částečně odkryté, ale přesto zakryté, tedy že vypadá jako něco, co není, je patrné i ve výpovědích využívajících sousloví zážitková pedagogika. Stručně si rekapitulujme několik způsobů využívání či hodnocení zážitkové pedagogiky, které - z našeho úhlu pohledu - nevedou $\mathrm{k}$ přesnějšímu určení identity tohoto oboru, ale spíše $\mathrm{k}$ jeho zamlžení a v konečném důsledku k oslabení jeho významu v hodnocení odborné pedagogické veřejnosti.

\subsection{Mínění první: „Děláme kurzy zážitkové pedagogiky“}

Jasnou nevolí, kterou musí vzbudit toto sousloví u odborníků, je jeho užívání při označování praktického edukativního oboru. „Dělám zážitkovku“ je heslo, které se zejména na webových portálech volnočasových pedagogů objevuje až nechutně často (napřr. prezentace či blogy instruktorů a lektorů na webových stranách www.instruktori.cz, www.aronga. cz, www.velkyvuz.cz, www.skritek.org aj.), často i $\mathrm{v}$ dalším upřesnění proč, pro koho či jak ten či ona „zážitkovku dělá“. Ačkoliv se název prosazuje stále častěji pro označování různorodých výchovných a vzdělávacích aktivit, a to zejména $\mathrm{v}$ prostředí praktických realizátorů takových činností, musíme se vůči této expanzi radikálně vymezit. Klasické, a stále pevně 
akceptované základní vymezení definuje, že: „Pedagogika je věda o výchově; jejím předmětem jsou jevy výchovy. Výchova a vyučování jsou praktické činnosti vychovatelů a učitelů. Jsou to dovednosti, které bývají považovány za umění. (...) Věda pedagogická nemůže arci přehlížeti bohatství pedagogické zkušenosti, ani význam osobních vychovatelských vzruchů, jak se nám projevují v pedagogické tradici rodinné nebo školské, ve školské organisaci, $\mathrm{v}$ různých metodách výchovných, nemůže také přezírati individuální vychovatelské umění, avšak toto bohatství zkušeností a dovedností jest často tak pestré a různorodé, oplývá tolika subjektivními, často si odporujícími hledisky, že je třeba vědecké revise, která by hodnotila zkušenosti a různé názory tyto zkušenosti provázející. Tím docházíme $\mathrm{k}$ soustavě myšlení o základech a pochodech výchovy a vyučování." (Chlup, Kubálek \& Uher, 1939, s. 307). Pokud nechceme ignorovat základní odlišení praxe a teorie, s nímž se setkáváme snad ve všech učebnicích pedagogiky, tedy že je rozdíl mezi záměrnou činností formující osobnost (výchova a vzdělávání) a mezi vědeckou disciplínou, která podstatu a zákonitosti této činnosti zkoumá (pedagogika), nemůžeme zážitkovou pedagogiku $\mathrm{v}$ tomto zavádějícím významu praktické realizace prožitkových situací používat.

Využívání jiného termínu pro pojmenování edukativní reality (výchova prožitkem, holistická výchova, zkušenostní učení aj.) není dehonestací oboru, ale možností odlišovat při komunikaci zřetelně odlišné diskursy.

\subsection{Mínění druhé: „Zážitková pedagogika do škol“"}

Pokusy etablovat zážitkovou pedagogiku jako adekvátní odpověd' na neduhy současného českého školství je zavádějící, a to od samého počátku těchto - jinak jistě uprímně míněných - snah. Snad neznalost kořenů a vývoje oboru samého, snad nedostatečné pedagogické vzdělání a ochota podlehnout prázdným řečnickým klišé bez důkladné racionální rozvahy zapříčinují, že se přitom zhusta používá zaklínadlo Komenského „školy hrou“. Samožrejmě, že fenomén hry coby prostředek rozvoje lidského života je od Komenského myšlení, stejně jako od jevů zkoumaných zážitkovou pedagogikou, neoddělitelný; to však $\mathrm{v}$ žádném př́padě neznamená, že schola ludus usiluje o proměnu vzdělávací instituce pouze v zábavné a hravé setkávání. Obdobné interpretace, nabalující se $\mathrm{v}$ písemné tradici a proměňující tak živé ideje Komenského ve všeobecně užívané floskule a fráze, se stávají opravdu spíše mýtem (Uhlírová, 2014) než adekvátní interpretací. Př́ćčinou je pravděpodobně žalostná neznalost původního díla, jehož adekvátnější překlad zní spíše „škola na jevišti“ (Komenský, 1947), nebot se jedná o využívání divadelních her, tedy formy dramatizace, ve vyučování. Pedagogický cíl Komenského, naplňovaný osmi divadelními hrami v latině (souboru předcházely ještě dvě divadelní hry, tematicky vztažené $\mathrm{k}$ Diogenovi kynikovi a Abrahamovi patriarchovi), jež těží tematicky z jazykové učebnice, biblických a antických př́běhů, se pokouší 
o přenesení encyklopedického vědění věcí přirozených, lidských, společenských i náboženských (celý název Komenského díla zní Schola ludus seu encyclopaedia viva, tedy Škola hrou aneb żivá encyklopedie) a byl určen pro předvádění desítkami herců (Kumpera, 1992). Přitom pedagogický cíl byl nadřazen čemukoliv dalšímu: pro postavy dialogu jsou bez ohledu na nějakou chronologii vybrány osobnosti z různých dob, které se autorovi hodí $\mathrm{k}$ jeho účelu. „O nějakém ohledu na historická fakta nemůže být ve hře Komenského i jinak ani řeči. Je to umělá, zcela ahistorická koncepce, přihlížející jen $\mathrm{k}$ tomu, aby se žáci naučili co největšímu počtu slovíček." (Komenský, 1970, s. 20). Pokud v některých momentech jeho dramatického díla lze sledovat i jisté umělecké kvality, jsou $\mathrm{v}$ díle bezděčně a nezáměrně, vyplývají „Z jeho spisovatelské kultivovanosti, postavené do služeb pedagogické funkce díla" (Uhlířová, 2003, s. 32). V současné době není dramatizace využívána ani tak $\mathrm{k}$ předávání obsahu učiva, ale spíše jako forma sebevyjádření $\mathrm{v}$ procesu (dramatické) výchovy, kdy nejsou témata určována výlučně pedagogem, ale jsou mnohem více otevřena skupině dětí, jejich vyspělosti a zájmu, nebot celostný proces tematizace a symbolizace, způsob práce $s$ herní situací, tedy verbální a nonverbální komunikace při vyjádření, je „dvojí způsob uchopení, nastolení či zpracování zážitku“ (Svozilová-Drahanská, 2007, s. 45). Škola hrou vyrůstá z jevištní podoby dramatizace, ale může být rozvíjena i formou psychodramatu či sociodramatu, využívající teorie sociální komunikace, hraní rolí a malých skupin, a to nejenom u dětí, ale i u dospělých (Tauber \& Tauberová, 1977).

Z neadekvátně používaného úsloví „škola hrou“, kdy se namísto dramatizace a dramatické výchovy rozprostírá význam až $\mathrm{k}$ libovolným aspektům zábavy protlačovaným neústrojně do školního prostředí, se stala typická ukázka onoho heideggerovského zakrývání, tvárícího se jako odkrývání - kdy se něco ve veřejném prostoru sděluje, ale kdy musí být navzdory takovému zahalujícímu vyprávění pravda opakovaně a trpělivě znovu odkrývána a vydobývána. Nedostatečné rozlišování a zaměňování Komenského zásad názornosti a aktivnosti, tedy získávání prímých zkušeností žákem, za zábavu edukace vede př́ímo $\mathrm{k}$ naivnímu přesvědčení, že jen a pouze formy a metody zážitkové pedagogiky jsou nejvhodnějším způsobem a prostředkem, jak napomoci zkvalitnění českého školství.

Přestože jsem zastáncem zážitkové pedagogiky, patřím $\mathrm{k}$ menšině odpůrců nazývání jakékoliv zábavné či hravé formy zážitkovou pedagogikou. Znalost hlubšího kontextu vývoje a kořenů nedovoluje tak ležérně a uvolněně používat termín $\mathrm{v}$ naprosto odlišném významovém kontextu, než v jakém vznikal. Proto také př̀i poctivě míněném úsilí přenášet formy a metody zážitkové pedagogiky do školního vyučování, dokonce do jednotlivých vyučovacích jednotek, např. při výuce klíčových kompetencí (Slejšková et al., 2011), považuji sice za smysluplné a užitečné, ovšem terminologicky naprosto nevhodné. Termín se již zcela odtrhl 
od svého původního významu (jenž bude přiblížen posléze) a transferoval do podoby metodiky pracující s emocemi při takřka jakékoliv analýze vzdělávacích potřeb, stanovení cílů, realizace programu a jeho reflexe. Domnívám se proto, že nabízené konkrétní aktivity, programové náplně či diskusní témata nemusí být nezbytně nutně nazývány zážitkovou pedagogikou, ale také projektovým vyučováním, prvky reformních pedagogických směrů a postupů akcentovaných již v první třetině 20. století, vždy pedocentricky orientovaných. Praktické využívání Komenského pedagogických zásad aktivity, přiměřenosti či názornosti jistě také nemusíme za každou cenu nazývat právě analyzovaným termínem. A pokud ano, pak bychom si měli být vědomi, že původní význam a obsah pojmu radikálně rozšiřujeme a podílíme se tak svým prrístupem na rozšiřování onoho Heideggerem zvýznamněného zdání, kdy popisovaný jev „vypadá jako...", ale ve skutečnosti zastírá dřive zřetelnou odkrytost poznávaného fenoménu.

\subsection{Mínění tř̌etí: „Zážitek je ,jen zážitek}

Odhalující - a současně zahalující - rovina výpovědí o lidském prožívání $s$ cílem získat životní zkušenosti je dána rovněž dalším rozměrem, který do tohoto sémantického pole vstupuje, charakterizovaným zejména etickým diskursem. Zkratkovitě jej můžeme naznačit dvojí prožitkovou orientací, uchopitelnou prostřednictvím etických konceptů hédonismu a eudaimonismu.
Pravděpodobně první z nich (tedy preferování slasti, požitkářského životního stylu) má na mysli Strouhal (2013), když představuje zážitek jako hlavního viníka soudobé pokleslosti politických a pragmatických př́stupů $\mathrm{k}$ výchově a vzdělávání. Zážitek chápe jako protipól ducha, uspořádanosti a hodnoty, protiklad myšlení a reflexe. Proto v souvislosti se zážitkovou pedagogikou hovoří pouze o plytkém formalismu, o nenaplněném př́slibu, o vyklízení myšlenky o intenzitě prožívání, o kontrastu zážitku a výchovy jako kultivace logem (s. 113-114), o „samospasitelném působení emocionálně zabarvené přímé zkušenosti na troskách knižního vědění pedagogického omylu tradice" (s. 115).

Prožitek však nemusíme a nesmíme vnímat pouze $\mathrm{v}$ jeho hédonistickém pojetí pokleslosti marketingových lákadel zážitkového průmyslu, nabízejícího stále nové a neotřelé zábavné zážitky. Konzumentský styl oblažování se a sběratelství požitků, adrenalinových výzev a opojného rozptýlení, rozkoše připravované na zakázku individuálních potřeb, není modus prožitku, o nějž usiluje zážitková pedagogika. Ba zcela naopak, za pozornost zde stojí spíše starořecký termín eudaimonia, tedy blaženost vyplývající ze ctnostného, nikoliv nutně zábavného jednání. Soulad činů a svědomí, slast nevystavená náhodě hédonistických rozkoší, protože pramenící ze strategie ušlechtilého jednání. A právě takové vyznění, tedy úsilí o smysluplnou existenci a osobnostní rozvoj v eudaimonistickém porozumění, můžeme bezpochyby vnímat $\mathrm{v}$ projektech reflektovaných zážitkovou pedagogikou. 
Snad nadbytečnou zmínkou je pak zopakování, že prožitek není v žádném textu zabývajícím se zážitkovou pedagogikou vnímán jako cíl a konečný efekt na rozdíl od činnosti agentur zážitkového průmyslu, která nikam dál či výš nemiří. Prožitek je prostředkem k získávání zkušeností, usilujícím o hodnotu každé do programu zařazené aktivity $\mathrm{v}$ dramaturgicky uspořádaném celku, a tím o smysl a zvyšující se smysluplnost existence konkrétního účastníka.

\subsection{Mínění čtvrté: „Zážitek bez reflexe nerozvíjí“}

Reflexe, tedy metody a techniky, jak napomoci přechodu od prožitku přes zážitek ke zkušenosti, si i u nás získává poslední dobou zaslouženou pozornost. Pomineme-li spíše populárně naučnou knihu Reitmayerové a Broumové (2007), můžeme se zaměřit na další ucelené pojednání Kolářovo (2013), kde se můžeme setkat i $s$ prímou polemikou $s$ názvem zážitková pedagogika. Autor odmítá tento termín a preferuje verzi „zkušenostně reflektivní učení", kterýžto pojem se snaží představit jako pevnou pedagogickou a psychologickou tradici, přestože kromě jediné výjimky (v podobě Reflective and Experiential Learning, což samo o sobě neznamená tak silnou spřežku obou směrů, jakou v sobě nese český navrhovaný novotvar) nepoužívá nikdo daný termín ani v Čechách, ani v zahraničí. Příčinou může být neznalost české tradice a zejména nezbytné vazby oboru na kinantropologické souvislosti výchovy $\mathrm{v}$ př́rodě: toto - pro zde prezentovaný soubor pedagogických analýz fundamentální - téma není vůbec reflektováno (pomineme-li drobnou zmínku na s. 51, vyjmenovávající v podstatě pouze názvy jednotlivých př́stupů a ústící $v$ nepř́liš povedený novotvar „zkušenostně reflektivní učení v prrírodě“ na s. 52). Závěr autora ve vztahu k pojmu zážitková pedagogika, totiž že by považoval „za smysluplnější, abychom i nadále tento prístup vnímali (v dobrém slova smyslu) jako aplikaci zkušenostně reflektivních principů učení do oblasti pedagogiky volného času“" (s. 28), sdílet nelze.

Proces reflexe (at' už ve formě sdílení prostřednictvím skupiny, nebo $\mathrm{v}$ podobě sebereflexe) znamená, že se vždy jedná o proces zvědomování, o logos. Taková racionalizace však v oblasti holistické výchovy (v analýzách zážitkové pedagogiky) není nezbytně nutnou součástí programu, a přesto může docházet $\mathrm{k}$ osobnostnímu rozvoji: prožitky kontaktu se smrtí a smrtelností, z náboženské konverze, ze vztahu lásky, či vědomí hodnoty domova a dálavy při cestování, při hledání smyslu života aj. mají obsažen rozvojový potenciál v bytostné struktuře existenciálního rozměru prožitku samého, aniž by musel být zdůvodňován racionální reflexí (jak bude podrobněji deklarováno dále).

Z hlediska české tradice výchovy v př́irodě a zážitkové pedagogiky se pozornost na reflexi (review, rozbor, cílenou zpětnou vazbu) u nás objevuje teprve až počátkem 90. let, pod vlivem získávaných zkušeností ze zahraničí (Pinkasová \& Svatoš, 1992), obdobně jako se začaly systematičtěji využívat lanové a překážkové parky, pečlivě 
obkreslované při zahraničních návštěvách (Hanuš, 1992). Do té doby se používaly zejména různorodé zpětnovazební možnosti pro hodnocení programů a jejich působnosti (tzv. hitace) či programové využití osobní zpětné vazby. Nikoliv reflexe jako nezbytné vytěžení programu pro edukační cíle. Při hlubším obeznámení se $s$ tradicí výchovných směrů, které se dnes sumují pod sousloví zážitková pedagogi$\mathrm{ka}$, je přesvědčivě patrné, že i bez reflexe (natož bez „skupinového reflektivního sezení") zkušenostní výchovný proces probíhal a probíhat může.

\subsection{Mínění páté: „V̌̌e začalo po roce $1990^{\circ}$}

Soudobý způsob teoretické práce a psaní odborných textů, využívající zejména elektronických databází časopiseckých publikací, je jistě velkolepou možností prrístupu ke zdrojům celosvětové provenience. Je rovněž velmi pohodlný, protože ve své pracovně prostřednictvím obrazovky počítače můžeme mít takřka veškeré publikace okamžitě $\mathrm{k}$ dispozici. Tato nesporná výhoda (spořící čas, energii i peníze) má však i svoji stinnou stránku: co bylo préed indexací odborných časopisů, to pro mnoho jedinců vlastně neexistuje. Žel, i v publikacích zabývajících se tématem zážitkové pedagogiky se referenční seznamy omezují na nejnovější texty a hranici čtvrtstoletí zpět překonává jenom málokterý z nich. Tak se však ztrácí kontinuita témat i termínů, dochází $\mathrm{k}$ významovým zjednodušením a k nereflektování (nerespektování) starších publikací, přestože ty mohou nést hodnotnější a propracovanější poselství než mnohé soudobé elektronické texty.

Na zastírání podstaty, smyslu a významu zde prezentovaného oboru se tak podepisuje i jistá pohodlnost potenciálních adeptů o hlubší porozumění, či dokonce lenost spokojující se s „vygooglováním“ hledaných slov. Nechceme-li však podlehnout svodům zdánlivého mínění, ale toužíme-li po skutečném poznání, neobejdeme se bez knihoven $s$ tištěnými texty a materiály, při hlubším zájmu o poznání historie pak ani bez archivů. Poté si uvědomíme, že kromě dnes používaného pojmenování je nezbytné porozumět i termínům pobyt a výchova $\mathrm{v}$ př́rodě, moderní formy výchovy $\mathrm{v}$ prrírodě, označení intenzivní rekreační režim či prázdninová pedagogika - a teprve poté, na úplném konci dlouhé vývojové linie se objevuje termín zážitková pedagogika. Bez znalosti vývoje a jeho kořenů nemůžeme adekvátně porozumět podstatě jakéhokoliv zkoumaného fenoménu. A protože se $\mathrm{v}$ českém prostředí objevuje tato nálepka opravdu až počátkem 90. let, snadno můžeme sklouznout do zdání, že dřívější minulost není v daném oboru důležitá a nemůže nám přinést žádné poučení.

\section{EPISTÉMÉ ZÁŽITKOVÉ PEDAGOGIKY}

\subsection{Poznání první: „Zkušenost je existenciální fakt a může se stát pedagogickým prostředkem“"}

Z vlastních životních okolností, z uměleckých záznamů výtvarných i slovesných, 
z filosofických a náboženských reflexí, stejně jako ze sociálního sdílení je evidentně patrná a intuitivně nahlédnutelná síla určitých prožitkových situací, proměňujících nejenom dosavadní nahlížení na sebe sama, ale také na své postavení ve společnosti i zakotvení ve světě, včetně způsobu porozumění těmto existenciálním souvislostem. Podíváme-li se na lidský zápas se smrtí a smrtelností (Epos o Gilgamešovi, 1997; Landsberg, 1990), na zkušenosti z náboženské konverze (Augustinus, 1990), na sílu vztahu lásky (Platón, 2005; Tichý, 2008) či hodnoty domova a dálavy při cestování (Homéros, 1996), na hledání smyslu života, at́ už v modu hédonistického potěšení, silného interpersonálního vztahu či v sociální angažovanosti a seberealizaci v práci (Frankl, 1994, 1997; Machovec, 2012), vždy můžeme vnímat jeden a tentýž jev: prožitek, který se stává hybným momentem pro transcendenci každodennosti, impulsem existenciální proměny, změnou hodnotové orientace.

Takovéto prožitkové situace, které mohou zapř́činit proměnu lidské existence, však nemusíme dohledávat pouze ve vrcholných výdobytcích kulturní tradice či filosofického myšlení. Nalézáme je bezpochyby $\mathrm{v}$ klíčových okamžicích vlastních životů, ale můžeme se s nimi setkat i při pokusech o ohlédnutí za účastí na několikadenních kurzech zejména pobytu $\mathrm{v}$ přírodě. $\mathrm{V}$ záznamech retrospekcí takových prožitků (Svoboda, 2013) se setkáváme nejenom $s$ deskripcí obtíží pobytu $\mathrm{v}$ prrírodě a se zápasem zdolávajícím bolest a fyzickou únavu, ale také $s$ překonáváním ostychu při spolubytí s ostatními, s úvaha- mi o životě a cestě do budoucnosti, o porozumění sobě samému, o dobru a smyslu života, o podstatě lidství, ale také třeba o proměně chování k vlastní babičce.

Pro poznání podstaty možného pedagogického vytěžení záměrně připravovaných prožitkových situací lze zdárně využít antropologický model homo viator, člověk poutník (Bednář, 2009). Je patrné, že taková cesta je opakem pohodlné existenciální zabydlenosti a stagnace postojů i myšlení, a že se naopak může stát symbolem hledání smyslu života a centra vlastní osobnosti. Několikadenní (nejenom putovní) kurz se zkrátka může stát jedním z biodromálních projektů, od nichž právem „očekáváme, že budou dávat našemu jednání trvalý smèr" (Bednář, 2009, s. 123, zvýrazněno autorem). Dopad silných zkušeností expedicí v př́irodě na životaběh i po velmi dlouhé době, dokonce i po dvaceti a třiadvaceti letech, byl dosvědčen i empirickým výzkumem (dosvědčujícím tedy skutečně trvalé celoživotní ovlivnění), př̌ičemž naprostá většina respondentů (99\%) vnímala tuto zkušenost jako signifikantní pro svůj následující život a $96 \%$ respondentů uvedlo, že tato zkušenost ovlivnila jejich současné sebepojetí; jedním z klíčových elementů utvářejících tento vliv je prritom prírodní prostředí (Takano, 2010).

\subsection{Poznání druhé: „Rozvojově využitá zkušenost je holistický fenomén"}

Cílem zde prezentované výchovné disciplíny (a teoretických deskripcí) 
není prioritně učení se konkrétním dovednostem (např. tábornickým, sportovním, komunikačním, kulturním či tvořivostním), ale cílem je zejména osobnostní rozvoj v holistické dimenzi kultivace lidské existence. $\mathrm{V}$ tom má blíže k filosofii výchovy či k pedagogické antropologii, totiž ve snaze o transcendenci každodennosti, o kombinaci vědění a ctnosti (Hábl, 2014), o kultivaci otevřenosti pro druhé, o probouzení zájmu o lidskost (Sedlář, 2014). A v tom rovněž může zážitková pedagogika navazovat adekvátně na Komenského, který usiloval o nutnost univerzálního vzdělání (všech, ve všem a veskrze) jako naplňování lidské přirozenosti - $\mathrm{k}$ níž patří aktivita, tudíž i hra, včetně školního divadla (Uhlírová, 2003). Posilování toho přirozeně lidského je však rovněž důvodem, proč se to podstatné na oboru tak obtížně formuluje a proč se podstatu výchovného úsilí nedaří deklarovat prostřrednictvím jednoznačných výpovědí, které jako jediné účelově orientovaná pedagogika respektuje.

Pro fenomény zkoumané zážitkovou pedagogikou je - vedle smyslu, daného cílem a zdůvodněním zařazení aktivity do programu - podstatným rovněž holistický ráz působení. Holismus je patrný např. na využívání prúrodního i kulturního prostředí; na celosti dramaturgického kontextu jednotlivých programů; na různorodosti používaných programových prostředků zasahujících variantní složky osobnosti (od pohybu, kreativních dílen, psychoher až po diskuse); na působení těchto programů nejenom na kognitiv- ní stránku účastníků, ale na celé jejich osobnosti, na znalosti, dovednosti i postoje (jinými slovy, můžeme zde být svědky antického kloubení „těla a ducha“, s akcentací vybraných hodnot). Z toho všeho je pak patrné, že takového úkolu se nemůže zhostit jedinec, ale musí se nezbytně jednat o týmovou spolupráci při př́pravě, realizaci i reflexi jednotlivých edukativních projektů, má-li holistický ráz vymezující svébytnost působení oboru být vskutku diferenciačním znakem. Jestliže výchova $\mathrm{v}$ př́rodě akcentuje zejména prostor a místo působení jako svůj specifický odlišující znak, výchova ve volném čase časovost, výchova dobrodružstvím jedinečný programový prostředek, pak pro výchovné snahy, jež chce zážitková pedagogika zkoumat, to není prvořadě zážitek, ale celkovost, celostní působení a vyznění. Tedy celostní či holistická výchova by mohlo být adekvátním označením praktického výchovného snažení (Jirásek, 2014), což je bezpochyby vhodnější než „dělání zážitkovky“.

$\mathrm{V}$ opozici vưči výlučně vzdělávacímu rozměru edukace tak stojí celostní výchova a zážitková pedagogika na stejné straně jako osobnostně sociální výchova, která je praktická, zosobněná a provázející - respektující (Valenta, 2013), kde je přihlášení se $\mathrm{k}$ holistickému rozměru komplexních zkušeností i k využitelnosti některých metodických postupů zážitkové pedagogiky výslovně artikulováno. Rovněž u artefiletiky (Slavík, 1997, 2001) a jejím důrazu na uchopení zážitku prostřednictvím logu spatřujeme celou řadu styčných témat společného zájmu. 


\subsection{Poznání třetí: „Zážitková pedagogika je pouze novější název pro specificky českou tradici výchovy $v$ přírodě“}

Jako adekvátní reakce na mínění, že před rokem 1990 (tedy před používáním termínu zážitková pedagogika) se daný obor vůbec nerozvíjel, nemůže být pouze povzdech, že lidé málo čtou starší materiály a že se tudíž pravdu odhalující znalosti postupně vytrácejí z obecného i expertního diskursu porozumění, ale spíše pádná argumentace ve formě stručné rekapitulace. Přesnější obrázek (kromě zdrojových textů uváděných dále) poskytuje i další shrnující a komentující literatura (Jirásek \& Svoboda, 2015; Neuman \& Hanuš, 2007).

\subsubsection{Pohybová rekreace, pobyt a pohyb $\mathbf{v}$ př́rodě}

Prvotní teoretické reflexe, které souvisejí $s$ naším tématem, se vztahují - snad překvapivě s ohledem na soudobé používání termínu zážitková pedagogika - $\mathrm{k}$ pohybové rekreaci, $\mathrm{k}$ pobytu a pohybu v př́irodě. Zejména dlouhá historie turistiky ve všech svých podobách a formách je pro obor neopominutelná (Hlaváček et al., 1967; Neuman et al., 2000). Výrazným myšlenkovým impulsem, který je v pedagogice volného času dobře znám a dostatečně studován, je skauting se svojí stoletou tradicí českého junáctví (Šantora et al., 2012), včetně jeho duchovního rozměru (Zajíc, 2000) či forem rodinného skautingu (Štorch, 1921). Mimořádné osobnosti a činnosti skautského spisovate- le a vychovatele Jaroslava Foglara, mimo jiné redaktora chlapeckých časopisů, který dokázal ovlivňovat prožívání nejenom desítek (a v souhrnu stovek) členů slavného skautského oddílu, ale také tisíců chlapců prostřednictvím čtenářských klubů (Pírek, 1990), je věnována zasloužená pozornost (Jirásek, 2007; Nosek-Windy, 1999; Zachariáš, 2007; Zapletal, 2007). Také od počátku paralelně jdoucí programová oblast, která se formovala vedle organizačně pevněji sevřeného skautingu, zdůrazňující zejména prírodu a přirozenost, romantiku a volný život, inspirující se přirozeností života původních obyvatel Ameriky, totiž lesní moudrost - woodcraft (Seton, 1991), je dobře známá jako podloží a zdroj soudobé zážitkové pedagogiky. $\mathrm{Z}$ obou zdrojů, a paralelně vedle nich, se profiloval i český tramping $(\mathrm{Hu}-$ rikán, 1990), hnutí bytostně neorganizované, svobodomyslné, preferující zejména víkendový únik $\mathrm{z}$ měst do lůna přírody, do trampských osad, specifické subkultury vymezující se vưči většinové - konzumní - společnosti.

\subsubsection{Výchova $v$ př́ŕrodě}

Edukační dimenze této formy rekreace je vnímána jako výchova $\mathrm{v}$ př́rodě, širokou skupinou pedagogů akceptovaný smèr (zahrnující $\mathrm{i}$ některé $\mathrm{z}$ dříve připomenutých zdrojových kořenů). Po druhé světové válce je patrná nejenom snaha o př́mé navázání na přerušenou kontinuitu, ale také úsilí o hledání nových forem a programových prostředků. Jedním $\mathrm{z}$ vysoce inspirativních projevů tohoto snažení, zejména v 60 . letech, bylo táboření s postupně vy- 
profilovanou sérií tábornických škol (Snopek et al., 1969; Stárek, 1974). Pohybová rekreace byla však i v jiných oblastech chápána a vnímána nejenom jako sféra odpočinku a zábavy, ale také jako prostor rozvoje osobnosti (Kocourek, 1972; Teplý, 1969).

\subsubsection{Moderní formy výchovy $\mathrm{v}$ přírodě, experimentální akce, intenzivní rekreační režim}

Moderní formy výchovy $\mathrm{v}$ př́rodě, jako jeden $\mathrm{z}$ nově používaných termínů v sedmdesátých letech 20 . století (vedle sousloví experimentální akce, podtrhávajícího hledání nových směrů, a vedle názvu intenzivní rekreační režim, propojujícího volný čas s náročností programu a jeho organizovaností), se od těch tradičních odlišují zejména programovou náplní. Ona modernost nezavrhuje ani turistické aktivity, ani táboření, ani sporty v prírodě, ale doplňuje je o kulturní pořady, hry a závody, a rovněž o speciální programy motivované príběhem či událostí a „burzy“, což je př́íležitost pro účastníky akce, aby předvedli své vlastní programy a prokázali své schopnosti (Gintel et al., 1977). Je to období tzv. experimentálních akcí, organizovaných sborem instruktorů pobytu $\mathrm{v}$ prýrodě a zapojujících rozmanité netradiční programové prostředky do scénáře jednotlivých projektů (které před realizací procházely náročným oponentním posuzováním). Období prodchnuté étosem inovací a experimentálního zkoušení, ale také evaluace a velmi podrobných závěrečných zpráv hodnotících programovou, personální i účastnickou dimenzi jednot- livých kurzů. Jedním z nejvíce známých projektů tehdejší doby byl Gymnasion, hlásící se již svým názvem k antickému pedagogickému ideálu výrazně usilujícímu o propojení těla a ducha. $\mathrm{Z}$ myšlenkových impulsů stojí za zopakování cílená práce s atmosférou (Gintel, 1973a), důraz na hru pro dospělé (Gintel, 1973b), míra organizovanosti a volnosti prázdninového času či překonávání sebe sama (Gintel, 1974), ale také fakt, že projekt byl koncipován na základě odborných požadavků, mj. že „jde o orientační výzkum spojený s prýímým ovlivňováním spontánnosti (schopnosti individua ,chopit se prŕležitosti', jeho ochoty měnit, modifikovat, přestavovat, přetvářet) a tvořivosti samotných účastníkü“ (Gintel, 1975, s. 10). Jedním z požadavků na experimentální akce je i jejich odborný zájem: „Objektem zkoumání je vztah instruktor - kolektiv účastníků a faktorů podmiňujících tento vztah; obě proměnné jsou v neustálé interakci, avšak toto vzájemné působení je ovlivňováno řadou okolností objektivního charakteru včetně vztahů uvnitř obou skupin. Tento neobyčejně složitý komplex proměnných dává možnost postavení mnoha výzkumných projektů.“" (-is-, 1974).

Ambice nejenom organizovat obdobné aktivity, ale také je reflektovat, metodicky zhodnocovat a pedagogicky zobecňovat se stala podložím pro sumarizaci informací ze závěrečných zpráv, pro deskripci instruktorských pozorování a jistý stupeň generalizace poznatků, pro publikační aktivitu týkající se např. odezvy mladých lidí na programovou nabídku, u nichž byl „zaznamenán růst sebedůvěry, samostatnos- 
ti, zájmu o vzdělání“ (Blanařová \& Slaměník, 1980, s. 505), nebo stimulačního vlivu kolektivu, který se projevuje i zvýšením aspirace (Slaměník, 1977), či nalézání správné míry mezi nedostatkem podnětů a jejich přemírou (Tajovský, 1977). Potvrzen byl závěr, že změny v životním způsobu účastníků jsou nejen časté, ale také relativně trvalé, evidentní je velice rychlý růst spontánní iniciativy, a zejména že „ve srovnání s jinými výchovnými prostředky má dobře odevzdaná akce prokazatelně nezvykle vysokou účinnost", resp. že v „současné době není znám jiný prostředek výchovy srovnatelné intenzity" (Holec, 1977, s. 4 a 9). V té době můžeme zaznamenat rovněž první (a na dlouhou dobu poslední) pokus o vědecké rozkrytí působnosti takto koncipovaných rekreačních aktivit (Holec \& Smékal, 1980; Holec et al., 1980).

Kromě rozmanitosti a programové variability jednotlivých používaných prostředků, kromě využivání svébytného prostoru různorodých exteriérů v okolí zatopeného lomu u Lipnice nad Sázavou, $s$ mimořádně působivým objektem vystaveným na principech organické architektury a $s$ jedinečným geniem loci emotivního působení (Holec, 2007) se stávají častěji opakovanými hesly doby akce, intenzita, atmosféra, hledání nových prvků. A hlavně: silný pedagogický zájem. „Cílem je, aby se pobyt $\mathrm{v}$ př́rodě stal výchovou v prírodě." (Smékal, 1986, s. 362, zdůrazněno autorem). Akcentována je nikoliv pasivní konzumace volného času, ale aktivní záliba, do níž musí být investováno značné množství úsilí a námahy, protože takové jednání přináší cílovou radost, zkvalitňuje „emoční bilanci člověka“" (Plzák, 1977, s. 14). Oproti deziluzi z konzumace pasivní zábavy je zdůrazňována spontaneita a svobodné rozhodování. Specifičnost výchovy ve volném čase však ,spočívá především v míře použitého přinucení" (Tajovský, 1977, s. 13), jež je v protikladném vztahu ke svobodnému jednání. Snad i proto se používá rovněž termín „intenzivní rekreační režimy“, který se hlásí nejenom k rekreaci, ale také k náročnému obsahu (Smékal, 1986).

\subsubsection{Prázdninová pedagogika}

Prázdninová pedagogika, jak zní další dobově podmíněné pojmenování (dané pravděpodobněi vázaností na název Prázdninová škola, tedy na organizaci, která tento obor v praktické realizaci i metodické a teoretické reflexi rozvíjela a rozvíjí), se zabývá celou řadou témat a problémových okruhů, jež se na kurzech objevovaly. Např́klad motivací účastníků, ale také rozměrem účastnické nesmělosti a jak $s$ ní pracovat, jak zacházet s problémovými jedinci (holdující alkoholu; chronický lenoch, flákač a povaleč; plaší a ostýchaví mladí lidé; naopak přezíraví, nafoukaní a povýšení; ale také mladé dívky vynikající nad ostatní krásou a přitažlivostí), skupinovým prožitkem, fenoménem autority při vedení a řízení, i komunikací obecněji. Je zřetelně patrné, že $\mathrm{v}$ tehdy živých tématech a prrístupech se odráží psychologické zaměření vůdčích instruktorů. $V$ literatuře z této doby (Gintel et al., 1980) se můžeme setkávat $s$ úvahami - dodnes zajímavě podanými - o výchovných specifikách 
v období adolescence, kdy jsou stimulovány intelektuální zájmy, snaha dobrat se vlastního názoru, ale také nesobecké jednání ve prospěch druhých. Primárním zájmem se stává sexualita, takže potenciální nebezpečí má být zažehnáno „sublimačními prostředky“, tzn. připraveným programem (hry, sporty, tanec, hudba), společnou činností a třeba i shovívavostí k některým projevům flirtu. Důraz na fenomén hry ve všech jeho podobách a souvislostech je pravděpodobně nejsilnějším ideovým impulsem oné doby.

Dodnes inspirativní mohou být výchovné zásady, jimiž se práce na kurzech Prázdninové školy měla řídit (Gintel, 1981), vymezení konkrétních pedagogických cílů (Břicháček, 1988a), výčet faktorů účinnosti, tedy reflexe pedagogických postupů a metod (Smékal, 1986), stejně jako specifika působení pedagoga (Břicháček, 1988b). Se znalostí soudobé nabídky programů, často pouze několikahodinových (neprávem se zaštitujících názvem zážitková pedagogika), je výrazným mementem tehdejší poznatek, že pět a půl dne je pro cílevědomou motivaci a přípravu účastníků pro přenos aktivních forem programu, ale také pro cílevědomou dramaturgii kurzu, málo (Gregor, 1981). Intenzita je dána nejenom programovou náplní, ale také využíváním časového fondu, kdy účastníci přijímají (při fyzicky náročném režimu) i 12 hodin programu denně (Holec, 1982). Pedagogické souvislosti nemohou opominout ani př́pravu odborníků, kteří se v této svébytné výchovné práci realizují, takže i systém a obsah vzdělávání instruktorů byl veřejně sdílen. Zatímco v minulosti byl akcent na náročnost velmi silný a projevoval se např. tím, že absolutorium instruktorského kurzu získalo obvykle $60-70 \%$ jeho účastníků s ohledem nejenom na vědomosti a schopnosti, ale také na talent (Kř́žz, 1989), v současnosti je vnímána př́íprava spíše jako osobnostně rozvojová, s možností účastnit se reparátů či si doplnit zápočty v následujícím ročníku instruktorského kurzu (Trávníčková et al., 2014). Vysoké nároky na úroveň instruktorů jsou patrné jak z programové šíře využívaných prostředků, tak z velikého vlivu, který má instruktor na účastníky. Ve vztahu pedagogiky volného času a školské (přesněji řečeno vysokoškolské) pedagogiky se další poznatky týkají i role učitele a instruktora (Holec et al., 1980).

Specifikem oboru je dramaturgie, promyšlená skladba programových prostředků, do dnešní doby pravděpodobně nejpůsobivější metodický vklad Prázdninové školy, který našel ocenění i v zahraničí (Leberman \& Martin, 2005; Martin, Franc, \& Zounková, 2004; Martin, 2001). Dramaturgie je procesem, který pomáhá nejenom strukturovat jednotlivé programy do scénáře se snahou o jejich maximální vytěžení - je to zejména způsob konstituce celého projektu, je to zvažování a výběr představ realizačního týmu. Projevuje se samozřejmě zejména volbou konkrétních programů (s ohledem na adekvátní zastoupení výše zmíněných různorodých programových zdrojů, ale také na jejich správné časové zařazení vzhledem $\mathrm{k}$ ročnímu období, rozvrhu dne i posloupnosti kurzu), ale je zejména ideovým podložím celého 
kurzu, je „obranou vůdčích myšlenek“. Z 24 prvotně formulovaných dramaturgických zásad je však nejzásadnější ona první: „V̌̌dycky platí: není důležité, jaké činnosti do programu akce zařadíme, ale jaké cíle jejich volbou sledujeme" (Gintel, 1982, s. 7). Vztah k dalším programům, rytmus, tempo a gradace, ovlivnění atmosféry, vliv prostředí, zvažování účastnické skupiny, načasování a specifika zahájení a zakončení, snaha o uměřenost a role spánku, stejně jako pauzy, nepravidelnosti a živelnosti, úsilí o harmonii, role romantiky a kouzla pojmenování, rozeznání vrcholů a tedy kulminace celého procesu, to vše je důležité a podstatné. Avšak předem stanovený cíl, který rozhoduje o smysluplnosti tohoto typu konání, je nejdůležitější moment, který by měl být i v současnosti více podporován a zdůrazňován. Dramaturgie byla a je stále promýšlena, se snahou o nové pojmové uchopení této svébytné metody obor konstituující (Čepeláková, Gintel, \& Gregor, 1985; Gintel, Gregor, \& Čepeláková, 1986). Připomeňme jen, že i při používání pojmu zážitková pedagogika se jako základní metodický princip vymezuje právě dramaturgie, $s$ př́ípadným rozlišením na dramaturgii teoretickou a praktickou (Paulusová, 2004), či $s$ upozorněním na vzájemnou závislost a propojenost jednotlivých prvků vytvářjících celou skládačku vazeb účastníků (jejich počet a specifikace skupiny), záměrů (témata a cíle), času (délka, termín), místa (interiéry a exteriéry) i zdrojů potřebných $\mathrm{k}$ realizaci (materiální, odborné) (Drahanská, 2009).

\subsubsection{Zážitková pedagogika}

$\mathrm{V}$ 80. letech se využívá různorodá terminologie promiskue. $\mathrm{Na}$ jednom místě tak mưžeme u ideje využívání přírodního prostředí $\mathrm{k}$ výchovným účelům vnímat kontext pedagogiky volného času, prázdninové pedagogiky, moderních forem výchovy v př́rodě i projektů s intenzivním rekreačním režimem (Gintel, 1984; 1986; Holec, 1982; Seminář Brno 81, 1981; Smékal, 1986). Pokusy o adekvátní terminologické postižení jevů, které byly reálně zakoušeny na kurzech, byly mnohačetné, včetně pozdějšího ojedinělého označení výchova $\mathrm{k}$ bytí (Gintel, 1996). Žádný $\mathrm{z}$ nich se však neujal $\mathrm{v}$ širší pedagogické odborné veřejnosti. Název zážitková pedagogika se naopak rozš́ríril velmi živelně, studenti jej používají v masovém měrítku pro své kvalifikační práce, ale odborná pedagogická veřejnost je vůči tomuto označení skeptická, resp. neprojevuje hlubší zájem, který by byl patrný $\mathrm{v}$ recenzovaných publikacích českých pedagogických periodik (Dvořáčková et al., 2014).

$S$ označením propojujícím výchovné snahy a pedagogické ambice teoretických analýz nikoliv s časovostí (pedagogika volného času), prostředím (výchova $\mathrm{v}$ př́rodě) či specifickými programovými prostředky (výchova dobrodružstvím a výzvou), ale $s$ fenoménem prožitku a zkušenosti, přichází u nás jako první jazyková verze „pedagogika zážitku“ (Vážanský, 1992), používá sevšaki „výchova prožitkem“(Neuman, 1999). Výraznější rozšířní v podobě „zážitková pedagogika“ je patrné v souvislosti se vznikem časopisu Gymnasion, na jehož úvodní (a tedy svým způsobem 
proklamativní) text (Jirásek, 2004) bývá nejčastěji odkazováno jako na dostačující porozumění termínu, jeho obsahu i širšímu kontextu. Protože je však pojem využíván $\mathrm{v}$ natolik odlišném kontextu a významu než původní vymezení (včetně nerespektování výslovného rozumění termínu v dimenzi teoretického uchopení výchovných procesů), můžeme se setkat i $s$ výzvou $\mathrm{k}$ terminologické obměně (Jirásek, 2014). Pokud totiž neakceptujeme historický vývoj a hodnotové, programové i metodické podloží, které obor postupně vytvářelo, pokud vytrhneme název z kontextu a opájíme se nedbale promyšleným slovem zážitek, podílíme se na zakrývání pravdy v heideggerovském smyslu, nikoliv na jejím odkrývání.

\subsection{Poznání čtvrté: „Zážitková pedagogika nezapadá do systému pedagogických věd“}

Z hlediska systematického uchopení $\mathrm{v}$ rámci klasifikace pedagogických disciplín se jedná o oblast, která překračuje jasné kriteriální hranice.

Nejedná se výlučně o pedagogiku volného času, jak je u nás dlouhodobě a úspěšně rozvíjena (Hájek, Hofbauer \& Pávková, 2003, 2008; Hofbauer, 2004; Kaplánek, 2012), a to ze dvou důvodů. Pedagogika volného času výslovně vnímá jako cílovou skupinu svého snažení děti a mládež, zatímco dospělí mají stanovovat cíle, organizovat uskutečňování těchto cílů a umožňovat dětem a mladým lidem podílet se na aktivitách (Hájek et al., 2008). Původní podoby výchovného působení, jež se dnes zaštitují termínem zážitková pedagogika, se však s odkazem na starořecký pedagogický ideál zaměřovaly zejména na adolescenty a mladé dospělé: „My jsme v pedagogice soustředili pozornost na dítě, kdežto Helény zajímal především dospělý člověk. Byl jediným cílem veškerých výchovných snah. Rekové nechtěli vychovávat odborníky, ale lidi, a to tak, aby v dalším životě mohli obstát při plnění jakéhokoliv úkolu, to znamená, aby se stali, bude-li to třeba, i dobrými odborníky. Šlo pochopitelně o ideál nikdy nedosažený, ale také - a to je nejdůležitější - o ideál, kterého se nikdy nežrekli.“ (Gintel, 1986, s. 518). Druhou odlišností je důraz nejenom na čas volný, ale zejména zdůraznění toho, jak „podpořit význam tzv. disponibilniho času, tedy času tvůrčí pracovní i nepracovní činnosti, při níž člověk nabývá nového poznání a zkušenosti, kdy rozvíjí své osobnostní schopnosti“ (Gintel, 1986, s. 518, zdůrazněno autorem). Prolínání pracovního (školního) a volného času je patrné napřr. u adaptačních a seznamovacích kurzů, u rozvoje lidských zdrojů formou „outdoor management training" (Svatoš \& Lebeda, 2005) apod., tedy u edukativních oblastí, jež mohou být pojímány jako součást pedagogiky a andragogiky.

Obdobně obtížné by bylo zařazování i do dalších pedagogických disciplín. Zážitková pedagogika, reflektující projekty holistické výchovy, zdůrazňuje a „do obrazu všestrannosti doplňuje to, co škola nedává', nebo na co ve školní výchově nezbývá čas" (Smékal, 1986, s. 359). Nepatří tedy do pedagogických disciplín věnujících 
se školnímu vzdělávání a jeho kontextovým souvislostem. Využívá však natolik rozmanitých prostředků z oblasti kulturních výdobytků, že termín výchova v přírodě rovněž není plně adekvátní. Nedá se zařadit do škatulek vědeckých klasifikací, a tak je existence oboru (v podobě výchovné specifikace, natož pedagogických úvah a reflexí) většinovou odbornou pedagogickou komunitou zpochybňována. Na druhé straně expertního zájmu, v oboru kinantropologie (věnující se analýzám člověka v pohybu), se rovněž velmi obtížně zakotvuje, přestože ten rekreaci, pobyt a pohyb v př́rodě vnímá jako svoji bytostnou součást ( $\mathrm{v}$ rámci disciplíny rekreologie, předmětem jejíhož zájmu je zejména pohybová rekreace). Protože se totiž nejedná výlučně o lidský pohyb a jeho analýzu, ale o existenciální možnosti lidského způsobu bytí $\mathrm{v}$ jeho holistické propojenosti, panuje na kinantropologických, stejně jako na pedagogických pracovištích jistý ostych vůči těmto snahám praktickým i teoretickým. Zážitková pedagogika je typickou ukázkou mezioborového tématu, reality překračující tradice karteziánského členění, svědectvím o nemožnosti svázat lidskou existenci do prýísných kritérií pouze racionální deskripce.

A přesto: holistická výchova prožitkem nabízí mladým lidem zkušenosti, které $\mathrm{v}$ jiných výchovných oblastech nejsou nabízeny. Napomáhá osobnostnímu rozvoji a prohlubování existence. Nejde pouze o výuku dovedností (např. pobytu či sportů $\mathrm{v}$ prrírodě). Úkolem holistické výchovy $\mathrm{v}$ př́rodě „není udělat $\mathrm{z}$ lidí horolezce, vodáky, turisty. My jen pomocí těchto aktivit chceme pracovat na osobním rozvoji účastníků. $\mathrm{Na}$ učení aktivit jsou zaměřeny různé outdoor cestovní kanceláře - ale my nejsme jednou z nich“" (Hanuš, 1992, s. 10).

\section{EMOTIVNÍ APEL NAMÍSTO ZÁVĚRU}

Oblast, kterou z nedostatku vhodnějšího termínu nazýváme holistickou výchovou a její deskripci zážitkovou pedagogikou, se nechce zabydlet na názorových či pojmových pozicích, které by byly neměnné a fixní. Celý předchozí vývoj je ukázkou tázajícího hledání a protikladu postojové i názorové rigidnosti. Různá mínění a zdání mohou podporovat postoje, že nemá valného významu a smyslu se tímto úzkým výsekem sociální reality na pomezí pedagogiky, andragogiky a kinantropologie zabývat. Epistemické zhodnocení prožitkových situací a rozvojových zkušeností však naznačuje, že mýty a nánosy, které se s názvem pojí, je nutné upřesňovat, rozkrývat hlubší souvislosti, zasazovat do kontextu. A tak napomáhat procesu, který postupným ohledáváním a odkrýváním projektů holistické výchovy a idejí zážitkové pedagogiky umožňuje přesnější porozumění jejich pravdivosti v modu existenciálního rysu, nikoliv pouze v logické bezrozpornosti racionálních deskripcí.

Z možného pole bezradnosti tak - zdá se mi - vyčnívá přesvědčení, které můžeme vnímat jako opravdové poznání, epistémé, nikoliv pouhé zdání či mínění, doxa: edukativní a osobnostně rozvojové projekty záměrně připravované speciálně 
školenými týmy, zahrnující různorodé programové prostředky (pohybové, tvořivostní, herní, diskusní aj.) kontextově uspořádané pomocí principů dramaturgie a využívající rozmanitých prostředí pro svoji realizaci, nabízené ve volném čase, avšak s možností přesahu do profesionální praxe (akcentující tak čas disponibilní) se svojí podstatou zaměřují na existenciální rozměr lidského způsobu bytí, usilují o holistickou zkušenost a její uchopení prostřednictvím logu. Proto má smysl se touto oblastí edukativní praxe zabývat i reflektivně, teoreticky a vědecky, at' už pro takový soubor idejí a názorů preferujeme název zážitková pedagogika, nebo se tento výraz stane pouze jedním v řadě, na nějž naváže jiný, usilující o adekvátnější pojmové uchopení.

A pokud celá tato sbírka argumentů ve prospěch pravdivého poznání jednoho dílč́ho oboru byla marná, pak musím na závěr připomenout detail, který pravděpodobně nemůže rozhojnit argumentaci o racionální impuls, ale jistě může alespoň emotivně naznačit velmi podstatné souvislosti. Se jménem Jana Amose Komenského je již svým názvem propojena Nadace Pangea, která si předsevzala stát se mecenášem rozvoje vzdělanosti a „,yzdvihovat ty, kterým se podařilo rozhojnit lidskou zkušenost o možnosti dosud netušené". Od svého vzniku v roce 1991 uděluje Nadace Pangea cenu inspirovanou Komenského humanismem, s názvem $Z a$ úsili o nápravu věci lidských, a to „klíčovým dílům, významným projektům, iniciativám a osobnostem. Obecný prínos $\mathrm{v}$ duchu tohoto ušlechtilého životního kréda J. A. Komenského, příspěvek $\mathrm{k}$ prohloubení lidského rozměru civilizace, je klíčovým kritériem pro udělení ceny." (www.nadacepangea.cz). $\mathrm{V}$ roce 2015 byla touto cenou poctěna rovněž Prázdninová škola Lipnice.

Tato práce vznikla $v$ rámci projektu Modely tèlesně zakotvené zkušenosti v teoretických základech záżitkové pedagogiky a jejich kinantropologických souvislostí (GAČR 16-19311S).

\section{LiterATURA}

Augustinus, A. (1990). Vyznání. Praha: Kalich.

Bednář, M. (2009). Pohyb člověka na biodromu: cesta životem z pohledu (nejen) kinantropologie. Praha: Karolinum.

Blanařová, L., \& Slaměník, I. (1980). Nové př́ístupy k organizování pobytu v přírodě v Socialistickém svazu mládeže. Teorie a praxe tělesné výchovy, 28(8), 505-507.

Břicháček, V. (1988a). Pedagogika přiměřená prázdninám (I). Teorie a praxe tělesné výchovy, 36(7), 442-444.

Břicháček, V. (1988b). Pedagogika přiměřená prázdninám (II). Teorie a praxe tělesné výchovy, 36(8), 504-506.

Čepeláková, J., Gintel, A., \& Gregor, J. (1985). Aktivni rekreační systémy a jejich dramaturgie: kompendium pro prázdninové pedagogy [Učebni texty Prázdninové školy SSM]. Nepublikovaný text. 
Drahanská, P. (2009). Puzzle a bábovky. Gymnasion, 6(1), 47-54.

Dvořáčková, A., Šulcová, M., \& Jirásek, I. (2014). Analýza metodologických postupů publikovaných prací v oblasti zážitkové pedagogiky. Pedagogika, 64(4), 407-421.

Epos o Gilgamešovi. (1997). Praha: Mladá fronta.

Frankl, V. E. (1994). Člověk hledá smysl: úvod do logoterapie. Praha: Psychoanalytické nakladatelství J. Kocourek.

Frankl, V. E. (1997). Vưle ke smyslu: vybrané prednášky. Brno: Cesta.

Gintel, A. (1973a). Gymnasion: část druhá - atmosféra. Metodické listy pro pobyt v prírodè, 3(3), 6-7.

Gintel, A. (1973b). Gymnasion: část první - vážná, avšak podstatná. Metodické listy pro pobyt vprírodè, 3(2), 2-4.

Gintel, A. (1974). Gymnasion: část šestá - otázky. Metodické listy pro pobyt v prírodě a turistiku, 4(2), 12-14.

Gintel, A. (1975). Gymnasion: část desátá - skladba programu. Metodické listy pro pobyt v príirodě a turistiku, 5(1), 8-10.

Gintel, A. (1981). Převádění na společné jmenovatele. Metodické listy pro tělovýchovně brannou cinnost, 9(2), 3-5.

Gintel, A. (1982). Obrana vůdčích myšlenek aneb dramaturgie. Metodické listy pro tělovýchovně brannou činnost, 10(2), 7-9.

Gintel, A. (1984). Význam prázdninových akcí SSM pro výchovu mládeže. Teorie a praxe tělesné výchovy, 32(10), 606-609.

Gintel, A. (1986). Moderní formy výchovy v prýrodè. Teorie a praxe tělesné výchovy, 34(9), 518-520.

Gintel, A. (1996). 12 dnů na přežití. In R. Hanuš \& M. Vážanský (Eds.), Výchova a pobyt $v$ prírodè na konci 20. století (sborník príspèvků konference) (s. 21-23). Praha a Olomouc: Nadace Pangea a Fakulta tělesné kultury Univerzity Palackého.

Gintel, A., Gregor, J., \& Čepeláková, J. (1986). Dramaturgie aktivnich rekreačnich systémů [Studijni texty Instruktorského kursu PŠ SSM]. Nepublikovaný text.

Gintel, A., Holec, O., Plzák, M., \& Tajovský, P. (1980). Prázdniny v pohybu aneb rukovět pro prázdninové pedagogy. Praha: Mladá fronta.

Gintel, A., Jarkovský, V., Roll, B., Slaměník, I., Stárek, M., Tajovský, P., \& Vraštilová, P. (1977). Pěsí turistika a pobyt v prírodě. Praha: Mladá fronta.

Gregor, J. (1981). Tři roky Prázdninové školy pro vysokoškoláky. Metodické listy pro tělovýchovnè brannou činnost, 9(2), 14-18.

Hábl, J. (2014). Amputovaná humanita aneb jak cizí je Komenského pedagogická antropologie té naší. Gymnasion, 8(2), 13-16.

Hájek, B., Hofbauer, B., \& Pávková, J. (2003). Pedagogika volného času. Praha: Univerzita Karlova.

Hájek, B., Hofbauer, B., \& Pávková, J. (2008). Pedagogické ovlivňováni volného času: současné trendy. Praha: Portál. 
Hájek, K. (2002). Tělesně zakotvené proživání. Praha: Karolinum.

Hanuš, M. (1992). Jarní dopis z Walesu. Lipnické metodické listy, 1(2-3), 10-12.

Heidegger, M. (1996). Bytí a čas. Praha: OIKOYMENH.

Hlaváček, M., et al. (1967). Turistika - I. Praha: Universita Karlova.

Hofbauer, B. (2004). Déti, mládež a volný čas. Praha: Portál.

Holec, O. (1982). Prázdninová škola ČÚV SSM (Dnešní pojetí prázdninové akce pro věkovou skupinu 16 až 19 let). Teorie a praxe tělesné výchovy, 30(8), 462-465.

Holec, O. (2007). Př́iběh Lipnice. Gymnasion, 4(1), 105-109.

Holec, P. (1977). Problematika metodického využití moderních forem pobytu v př́rodě v SSM. Metodické listy pro tělovýchovnè brannou činnost, 7(2), 4-9.

Holec, P., \& Smékal, V. (1980). Výchovné aspekty rízené rekreační činnosti. Acta polytechnica: práce ČVUT v Praze 15, 6(3), 81-89.

Holec, P., Smékal, V., Matějů, M., \& Tománek, P. (1980). Dobrovolné prázdninové aktivity Socialistického svazu mládeže a komunistická výchova na vysokých školách [Závèrečná zpráva]. Nepublikovaný text.

Homéros. (1996). Odysseia. Praha: Petr Rezek.

Hudlička, P. (2003). Proživání - zkušenost - životni svèt, aneb O cestách do svèta na zkušenou. Praha: Triton.

Hurikán, B. (1990). Déjiny trampingu. Praha: Novináŕ.

Chlup, O., Kubálek, J., \& Uher, J. (Eds.). (1939). Pedagogická encyklopedie, II. díl. Praha: Novina, tiskařské a vydavatelské podniky.

-is-. (1974). Zásady pořádání experimentálních akcí. Metodické listy pro pobyt v prírodě a turistiku, 4(3), 14.

Jirásek, I. (2001). Prožitek a možné svèty. Olomouc: Univerzita Palackého.

Jirásek, I. (2004). Vymezení pojmu „zážitková pedagogika“. Gymnasion, 1(1), 6-16.

Jirásek, I. (Ed.). (2007). Fenomén Foglar. Praha: Prázdninová škola Lipnice.

Jirásek, I. (2014). Inzerát na název. Gymnasion, 8(1), 11-19.

Jirásek, I., \& Svoboda, J. (2015). Putováni a smysl života: promèna člověka v zimni prírodè. Olomouc: Univerzita Palackého.

Kaplánek, M. (Ed.). (2012). Čas volnosti - čas výchovy: pedagogické úvahy o volném čase. Praha: Portál.

Kirchner, J. (Ed.). (2005). Prožitek a dobrodružství proživání. Ústí nad Labem: Univerzita J. E. Purkyně a Asociace psychologů sportu České republiky.

Kirchner, J., \& Hogenová, A. (Eds.). (2001). Prožitek v kontextu dnešní doby. Praha: Univerzita Karlova.

Kirchner, J., \& Kavalíŕ, P. (Eds.). (2003). Prožitek a tělesnost. Praha: Asociace psychologů sportu ČR.

Kirchner, J., \& Louka, O. (Eds.). (2007). Prožitek - zážitek - zkušenost. Ústí nad Labem: Univerzita J. E. Purkyně a Asociace psychologů sportu ČR. 
Kocourek, J. (1972). Pobyt v př́rodě a výchova. Metodické listy pro pobyt v prírodě, 2(1), 13-15. Kolár, J. (2013). Práce s reflexí u lektorů osobnostné sociálního rozvoje. Brno: Masarykova univerzita.

Komenský, J. A. (1914). Theatrum universitatis rerum. In J. Kvíčala et al. (Ed.), Veškerých spisů Jana Amosa Komenského svazek 1 (s. 49-129). Brno: Ústřední spolek jednot učitelských na Moravě.

Komenský, J. A. (1947). Škola na jevišti. Brno: Komenium.

Komenský, J. A. (1970). Škola hrou, část VIII., akt 1. Praha: Ústřední dům umělecké tvořivosti.

Křižz, P. (1989). Př́prava instruktorů Prázdninové školy SSM. Teorie a praxe tělesné výchovy, 37(11), 641-642.

Kumpera, J. (1992). Jan Amos Komenský: poutnik na rozhrani věkủ. Ostrava: Amosium servis a Nakladatelství Svoboda.

Landsberg, P. L. (1990). Zkušenost smrti. Praha: Vyšehrad.

Leberman, S. I., \& Martin, A. J. (2005). Applying dramaturgy to management course design. Journal of Management Education, 29(2), 319-332.

Machovec, M. (2012). Smysl lidské existence. Praha: Akropolis.

Martin, A. J. (2001). Dramaturgy: an holistic approach to outdoor education. Australian Journal of Outdoor Education, 5(2), 34-41.

Martin, A., Franc, D., \& Zounková, D. (2004). Outdoor and experiential learning: an holistic and creative approach to programme design. Aldershot: Gower.

Neuman, J. (1999). Překážkové dráhy, lezecké stěny a výchova prožitkem. Praha: Portál.

Neuman, J., \& Hanuš, R. (2007). Kristova léta školy prázdninového času. Gymnasion, 4(1), $17-55$.

Neuman, J., et al. (2000). Turistika a sporty v prírodě: prehled základnich znalostí a dovedností pro výchovu v prírodè. Praha: Portál.

Nosek-Windy, V. (1999). Jestrábi perutè: povidáni o foglarovkách. Praha: Olympia.

Patočka, J. (1996). Nejstarši recká filosofie: prednášky z antické filosofie. Praha: Vyšehrad.

Paulusová, Z. (2004). Smysl a význam dramaturgie při př́ípravě akcí zážitkové pedagogiky. Gymnasion, 1(1), 85-89.

Pinkasová, M., \& Svatoš, A. (1992). Podzimní zpráva z Británie. Lipnické metodické listy, $1(2-3), 10-12$.

Pírek, Z. (1990). Čtenáršé kluby Jaroslava Foglara. Brno: Delfín.

Platón. (2005). Symposion. Praha: OIKOYMENH.

Plzák, M. (1977). Problematika sociálního začleňování do kolektivu v rámci pohybové rekreace mládeže. Metodické listy pro télovýchovně brannou ćinnost, 7(3), 14-17.

Reitmayerová, E., \& Broumová, V. (2007). Cílená zpètná vazba: metody pro vedoucí skupin a učitele. Praha: Portál.

Sedlář, P. (2014). Praporečník míru a lidskosti. Gymnasion: časopis pro zážitkovou pedagogiku, 8(2), 6-7. 
Seminář Brno 81. (1981). Metodické listy pro télovýchovné brannou činnost, 10(2), 2-3.

Seton, E. T. (1991). Kniha lesni moudrosti. Praha: Olympia.

Slaměník, I. (1977). Některé otázky vzniku a vývoje moderních forem pobytu v přírodě v rámci SSM. Metodické listy pro télovýchovnè brannou činnost, 7(2), 9-11.

Slavík, J. (1997). Od výrazu k dialogu ve výchově: artefiletika. Praha: Univerzita Karlova.

Slavík, J. (2001). Umèní zážitku, zážitek uméní: teorie a praxe artefiletiky, 1. dill. Praha: Univerzita Karlova.

Slejšková, L., Drahanská, P., Langrová, J., \& Trčková, R. (2011). Škola zážitkem: zážitková pedagogika pri výuce klícových kompetencí a hodnocení žákỉ. Praha: Prázdninová škola Lipnice.

Smékal, V. (1986). Výchova a pobyt v př́rodě. Teorie a praxe télesné výchovy, 34(6), 358-362.

Snopek, V., et al. (1969). Tábornická škola. Praha: Mladá fronta

Stárek, M. (1974). Tábornické školy jak byly, jak jsou a jak by měly být. Metodické listy pro pobyt v prírodě a turistiku, 4(3), 15.

Strouhal, M. (2013). Teorie výchovy: $k$ vybraným problémuim a perspektivám jedné pedagogické discipliny. Praha: Grada.

Svatoš, V., \& Lebeda, P. (2005). Outdoor trénink: pro manažery a firemní týmy. Praha: Grada. Svoboda, J. (2013). Interpretativni fenomenologická analýza zkušenosti účastnika kurzu PŠL Život je gotickej pes 2011. [Diplomová práce], Univerzita Palackého, Olomouc.

Svoboda, K. (Ed.). (1962). Zlomky predsokratovských myslitelů. Praha: Nakladatelství Československé akademie věd.

Svozilová-Drahanská, P. (2007). Proces tematizace a symbolizace v herním a jevištním jednání. Brno: Janáčkova akademie múzických umění.

Šantora, R., Nosek, V., Janov, S., \& Dostál, V. (2012). Skautské století: dobrodružný príběh 100 let českého skautingu. Praha: Junák - svaz skautů a skautek ČR ve spolupráci s vydavatelstvím Mladá fronta.

Štorch, E. (1921). Tábornická príručka: organisace rodinného skautinku. Praha: České lidové knihkupectví a antikvariát.

Tajovský, P. (1977). Rekreační pobyt $\mathrm{v}$ př́rodě v životním způsobu mladého člověka a jeho vývojové perspektivy $\mathrm{v}$ tzv. moderních formách pobytu v př́ŕodě $\mathrm{v}$ zájmové činnosti SSM. Metodické listy pro télovýchovnè brannou cinnost, 7(3), 10-14.

Takano, T. (2010). A 20-year retrospective study of the impact of expeditions on Japanese participants. Journal of Adventure Education \& Outdoor Learning, 10(2), 77-94.

Tauber, J., \& Tauberová, V. (1977). Komenského Škola hrou znovu oživená: príspèvek k výchově a vzděláváni dospělých. Praha: Státní pedagogické nakladatelství.

Teplý, Z. (1969). Pohybová rekreace. Praha: Universita Karlova.

Tichý, L. (2008). Chvála lásky: interpretace a úcinky 13. kapitoly Prvního listu Korintanuim. Olomouc: Univerzita Palackého.

Trávníčková, S., Hanuš, M., Benda, V., Kovaříková, Š., \& Štefl, K. (2014). Jak a v čem se vzdělávají instruktoři zážitkových akcí? Gymnasion, 8(2), 55-66. 
Uhlírová, J. (2003). Role hry v Komenského pedagogické koncepci. Praha: Univerzita Karlova.

Uhliŕová, J. (2014). Je Komenského škola hrou mýtem? Gymnasion, 8(2), 19-26.

Valenta, J. (2013). Didaktika osobnostni a sociálni výchovy. Praha: Grada.

Vážanský, M. (1992). Volný čas a pedagogika zážitku. Brno: Masarykova Univerzita.

Zachariáš, J. (2007). Stoletý hoch od Bobrí re reky. Praha: Ostrov.

Zajíc, J. (2000). Duchovní život na vzdělávací akci. In V. Břicháček et al. (Eds.), Čítanka pro instruktory. Praha: Junák - svaz skautů a skautek ČR.

Zapletal, M. (2007). Záhady a tajemství Jaroslava Foglara. Praha: Knižní klub.

prof. PhDr. Ivo Jirásek, Ph.D.,

Univerzita Palackého v Olomouci, Fakulta tělesné kultury, katedra rekreologie;

e-mail:ivo.jirasek@upol.cz

\section{JIRÁSEK, I. Doxa and epistémé of the Theory of Education through Direct Experience}

This article, in the form of a review study, offers an overview of the development of a discipline on the boundaries of pedagogics, adult education theory and kinanthropology (anthropology of movement), i.e. education in the outdoors (nature) and its transformation into the modern form of education outdoors - the pedagogy of nature camps and trips and experiential pedagogy. The article first looks at certain clichés, views and judgements associated with the area that the author believes to be wrong (doxa) because they fail to distinguish between experiential education in theory and the field in practice; the diffusion of the concept of such education in school milieux in inadequate form; he lack of full appreciation of the potential use of experience in educational discourse; the perception of critical reflection as an essential part of this type of personality development; the relationship to literary sources purely from the last twenty-five years. The author then goes on to offer an idea that he considers to be a relevant form of understanding (epistémé), i.e. that experience as an existential fact can become a means of personality development; this approach is characterised by stress on the holistic dimension of the effect; he offers a review of the previous terms used in relation to the theme, against the background of which it is possible to achieve a deeper understanding of the history and terminological development of the discipline. Finally he argues that it is impossible to insert this specific pedagogical theme (or discipline) into conventional classifications of educational sciences.

Keywords: experience, physical recreation, outdoor education, experiential pedagogy, lived knowledge. 